University of Pennsylvania Carey Law School

Penn Law: Legal Scholarship Repository

Faculty Scholarship at Penn Law

8-2015

\title{
Ratification, Reporting, and Rights: Quality of Participation in the Convention against Torture
}

Cossette D. Creamer

University of Minnesota - Twin Cities

Beth A. Simmons

University of Pennsylvania Carey Law School

Follow this and additional works at: https://scholarship.law.upenn.edu/faculty_scholarship

Part of the Ethics and Political Philosophy Commons, Human Rights Law Commons, International Law Commons, International Relations Commons, Law and Politics Commons, National Security Law Commons, Policy Design, Analysis, and Evaluation Commons, Public Law and Legal Theory Commons, and the Public Policy Commons

\section{Repository Citation}

Creamer, Cossette D. and Simmons, Beth A., "Ratification, Reporting, and Rights: Quality of Participation in the Convention against Torture" (2015). Faculty Scholarship at Penn Law. 1682.

https://scholarship.law.upenn.edu/faculty_scholarship/1682

This Article is brought to you for free and open access by Penn Law: Legal Scholarship Repository. It has been accepted for inclusion in Faculty Scholarship at Penn Law by an authorized administrator of Penn Law: Legal Scholarship Repository. For more information, please contact PennlawIR@law.upenn.edu. 


\section{PROJECT MUSE}

\section{Ratification, Reporting, and Rights: Quality of Participation in the Convention against Torture}

Cosette D. Creamer, Beth A. Simmons

Human Rights Quarterly, Volume 37, Number 3, August 2015, pp. 579-608 (Article)

Published by Johns Hopkins University Press DOI: $10.1353 / h r q .2015 .0041$

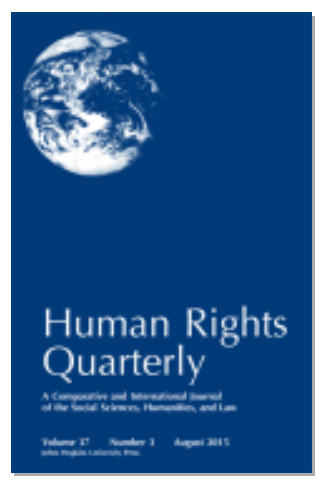

$\Rightarrow$ For additional information about this article http://muse.jhu.edu/journals/hrq/summary/v037/37.3.creamer.html 


\title{
HUMAN RIGHTS QUARTERLY
}

\section{Ratification, Reporting, and Rights: Quality of Participation in the Convention against Torture}

\author{
Cosette D. Creamer* \& Beth A. Simmons**
}

\begin{abstract}
The core international human rights treaty bodies play an important role in monitoring implementation of human rights standards through consideration of states parties' reports. Yet very little research explores how seriously governments take their reporting obligations. This article examines the reporting record of parties to the Convention against Torture, finding that report submission is heavily conditioned by the practices of neighboring countries and by a government's human rights commitment and institutional capacity. This article also introduces original data on the quality and responsiveness of reports, finding that more democratic-and particularly newly democratic-governments tend to render higher quality reports.
\end{abstract}

\section{INTRODUCTION}

The ratification of international human rights treaties provokes commentary and analysis by policymakers, lawyers, advocates, and academics alike. Some

* Cosette D. Creamer holds a J.D. from Harvard Law School and is a Ph.D. Candidate in the Department of Government, Harvard University.

** Beth A. Simmons is the Clarence Dillon Professor of International Affairs in the Department of Government, Harvard University.

For helpful feedback, the authors would like to thank Christopher Fariss, Katerina Linos, Yonatan Lupu, Gerald Neuman, Kathryn Sikkink, and participants in the WCFIA-HLS International Law-International Relations Workshop, the Conference on the Domestic Politics of International Human Rights Agreements held at the Niehaus Center for Globalization and Governance, Princeton University, and the Human Rights and Constitutionalism thematic working group at the University of Oslo, Faculty of Law and Norwegan Centre for Human Rights. The authors also thank Diana Li for providing invaluable research assistance. 
view ratification as cheap talk on the part of states, while others see it as a serious commitment that pledges a country's reputation. A fair amount of literature on human rights treaties assumes that ratification matters in some way: it begins a process of socialization of elites, stimulates public mobilization, provides ammunition for litigation, and in some cases sends a costly signal of a government's intention to refrain from human rights violations. Treaty ratification also initiates a communicative process that connects a polity with the international human rights regime at various points in time. This "constructive dialogue" centers around state reports on implementation submitted to the treaty monitoring body. Not only is reporting a legal obligation within all human rights conventions, ${ }^{1}$ it is also the primary method to generate information and increase transparency about implementation of and compliance with the treaty.

Reporting and monitoring have become increasingly common aspects of international governance across issue areas, ${ }^{2}$ yet there is surprisingly little analysis of the politics of such information provision or its effects on state behavior. Claims about the importance of information and monitoring in facilitating cooperation and compliance with international agreements vary. In the context of human rights treaties, some claim that the reporting system-and information about compliance in particular-is the regime's primary tool to ensure that states fulfill their obligations. Others disparage the entire process as a bureaucratic exercise with little to no substantive effect on compliance and assert that state reporting to treaty bodies is shamefully inadequate. Despite almost three decades of experience with the international human rights reporting regime, we lack a comprehensive understanding of

1. Office of the United Nations High Commissioner for Human Rights, The United Nations Human Rights Treaty System: An Introduction to the Core Human Rights Treaties and Treaty Bodies, available at http://www.ohchr.org/Documents/Publications/FactSheet30en. pdf.

2. See Daniel Bodansky, The Role of Reporting in International Environmental Treaties: Lessons for Human Rights Supervision, in The Future of UN Human Rights Treaty Monitoring 361, 362 (Philip Alston \& James Crawford eds., 2000); Thomas Conzelmann, Beyond the Carrot and the Stick: State Reporting Procedures in the World Trade Organization and the Organization for Economic Cooperation and Development, in International Organizations And Implementation: Enforcers, managers authorities? 35 (Jutta Joachim, Bob Reinalda \& Bertjan Verbeek Routledge eds., 2008); Ryan Goodman \& Derek Jinks, Socializing States: Promoting Human Rights through International Law (2013); Ronald B. Mitchell, Sources of Transparency: Information Systems in International Regimes, 42 INT'L STUD. Q. 109 (1998); Michael O'Flaherty, Human Rights and the UN: Practice before the Treaty Bodies (1996); Theodore J. Piccone, Catalysts for Change: How the UN's Independent Experts Promote Human RiGHTS (2012). The International Labor Organization has one of the most robust records of self-reporting, presumably due to its stronger procedure for supervision. International Labour Organisation, Constitution of the International Labour Organisation and Standing Orders of the International Labour Conference, art. 22 (1989). See also Abram Chayes, Antonia Handler Chayes and Ronald B. Mitchell, Managing Compliance: A Comparative Perspective, in Engaging Countries: Strengthening Compliance With International Environmental AcCords 39 (Edith Brown Weiss \& Harold Jacobson eds., 1998). 
this process and to our knowledge there have been few systematic attempts to evaluate these claims. Very little research explores just how seriously (if at all) governments take this reporting obligation or the potential influence of the periodic review process on states' actual human rights practices. ${ }^{3}$

This article examines the record of state reporting to one treaty monitoring body: the Committee Against Torture (CmAT). While states do provide some information to treaty bodies about their implementation of human rights agreements, the regularity and the quality of these reports varies tremendously. This article seeks to explain these patterns in the context of the reporting regime for the Convention Against Torture (CAT), a regime that governs politically-sensitive rights for which it is particularly difficult to hold governments accountable via self-reporting. ${ }^{4}$ In fact, the CAT's reporting record is the lowest among the specialized human rights treaties (the Convention on the Elimination of Racial Discrimination, the Convention on the Elimination of Discrimination Against Women, and the Convention on the Rights of the Child). ${ }^{5}$ Government practices falling under the CAT's jurisdiction are intimately linked with a country's internal security or stability. In addition, the CAT covers a number of politically sensitive areas typically considered to be at the heart of state sovereignty, such as the administration of prisons, the organization and the management of police and paramilitary forces, the criminal justice system, and the granting of asylum. In all these areas of governance, states' parties have greater incentives to obscure or render less than transparent information regarding their practices. Why then do some states comply with their reporting obligations while others do not? And most importantly, how and why does the quality of reporting vary so much across states?

Reporting quality has not been investigated systematically to date. Yet it is revelatory: if governments deny or refuse to identify implementation deficiencies, the posited benefits of the reporting process may be elusive. For this reason, this article introduces original data on the quality and responsiveness of every report submitted to the CmAT since its inception. A report's score on quality and responsiveness is based on its transparency and on how well the report engages with the Committee's concluding observations. To be

3. On the structure, function, and legitimacy of the human rights treaty bodies, see ANNE F. Bayefsky, The UN Human Rights Treaty System: Universality at the Crossroads (2001); Future of UN Treaty Monitoring, id; UN Human Rights Treaty Bodies: Law and Legitimacy (Helen Keller \& Geir Ulfstein eds., 2012). For one of the few studies on the international human rights treaty periodic review process, see Lawrence J. LeBlanc, Ada Huibregtse \& Timothy Meister, Compliance with the Reporting Requirements of Human Rights Conventions, INT'L J. Hum. Rts. 789 (2010).

4. Convention Against Torture and Other Cruel, Inhuman or Degrading Treatment or Punishment, adopted 10 Dec. 1984, G.A. Res. 39/46, U.N. GAOR, 39th Sess., U.N. Doc. A/39/51 (1985), 1465 U.N.T.S. 85 (entered into force 26 June 1987) [hereinafter CAT].

5. LeBlanc et al., supra note 3 . 
clear, this does not measure the accuracy of the information provided but rather the extent to which a government's report explicitly recognizes and is responsive to shortcomings in implementation of and compliance with the treaty's terms. In this respect, a report's quality score reverses standard indexes of a country's human rights practices. Thus, a higher quality represents more self-critical reports that admit to weaker implementation of and compliance with the prohibition against torture. A focus on report quality permits evaluation of the level of states' engagement with the periodic review process, by analyzing reporting not simply as a procedural obligation but as an opportunity for government officials to learn about and become socialized into the international human rights regime. ${ }^{6}$ This research is important to eventually understand whether, and how, voluntary reporting contributes to appropriate human rights practices on the ground.

This article proceeds as follows: Section II provides a brief summary of the treaty monitoring body process and the claims made about this system's (un) importance. Section III examines why a government would bother to submit a report to a human rights treaty monitoring body. There is strong evidence of a mimetic process within the CAT reporting regime, with the probability of report submission increasing as more neighboring countries fulfill their reporting obligations. Measures of institutional capacity-particularly the existence of a national human rights institution-and measures of human rights commitment also largely explain which states report. Countries that have recently transitioned to democracy or experienced a recent improvement in democratic governance, on the other hand, have a lower probability of reporting than more stable regimes.

Section IV turns to the quality of reporting. It considers various factors that influence the ability and willingness of parties that do participate in the CAT reporting regime to render thorough, transparent, and responsive reports. While the degree to which a government is responsive to Committee concerns is positively correlated with a state's institutional capacity and size, domestic political openness-democratic institutions and a recent transition to democracy-contribute to more thorough and transparent reports. Furthermore, newly democratized countries are much more likely to submit a highly responsive report. These findings suggest that the reporting process may be very important for at least a subset of countries that want to tap into international expertise and signal domestic audiences of their commitment to best human rights practices. Section $V$ concludes with directions for further research.

6. On the democracy- and deliberation-enhancing effects of reporting requirements, see Robert O. Keohane, Stephen Macedo, \& Andrew Moravscik, Democracy-Enhancing Multilateralism, 63 INT'L ORG. 1, 18 (2009). 


\section{THE ROLE OF REPORTING IN THE INTERNATIONAL HUMAN RIGHTS TREATY SYSTEM}

The legal regime for international human rights assumes that accountability is a potential pathway towards implementing treaty obligations and eventually improving rights practices. For this reason, every major human rights convention establishes an independent oversight committee to monitor treaty implementation. ${ }^{7}$ These committees are comprised of ten to twentythree independent experts nominated and elected by states' parties for fixed, renewable terms of four years. ${ }^{8}$ By virtue of treaty ratification, states must submit to each committee periodic reports on the legislative, judicial, administrative, or other measures adopted to give effect to human rights obligations. ${ }^{9}$ In this sense, periodic reporting is an aspect of "procedural compliance" with a government's treaty obligations. ${ }^{10}$

Most committees employ the same basic framework for "consideration," "study," or "examination" of reports. Although not required, all committees consider reports in the presence of government representatives, employing the approach of a "constructive dialogue" during which the committee engages representatives, acknowledges progress made, and identifies areas for improvement. ${ }^{11}$ Following this exchange, all committees publish some form of "concluding observations," though most commentators agree that these recommendations are not legally binding on states parties. ${ }^{12}$ All state reports and committee observations are made public. ${ }^{13}$

Notwithstanding the central role reporting plays in encouraging implementation and compliance with treaty obligations, ${ }^{14}$ the system is often criticized as unimportant, inadequate, and even "in crisis." ${ }^{15}$ Late and nonreporting is fairly widespread. For example, of the 147 states parties to the CAT in June 2011, thirty (20.4 percent) had still not submitted their initial report (with Somalia's initial report the latest at twenty years) and 122 (83

7. This requirement is found in CAT, supra note 4, art. 17.

8. The Committee Against Torture is the smallest of all treaty bodies, with ten members total. See id. art. 17(1).

9. CAT requires states parties to submit an initial report within one year of ratification or accession, and subsequent periodic reports at least every four years. See id. art. 19(1).

10. Ann Kent, China, the United Nations, and Human Rights 236 (1999).

11. U.N. International Human Rights Instruments, Report on the Working Methods of the Human Rights Treaty Bodies Relating to the State Party Reporting Process: Note by the Secretariat, U.N. Doc. HRI/MC/2005/4 (23 May 2011), at 7.

12. Michael O'Flaherty, The Concluding Observations of United Nations Human Rights Treaty Bodies, 6 Hum. Rts. L.Rev. 27, 36 (2006).

13. The Office of the High Commissioner of Human Rights now publishes all state reports on its website, available at http://tb.ohchr.org/.

14. Philip Alston, Effective Functioning of Bodies Established Pursuant to United Nations Human Rights Instruments: Final Report of the Independent Expert, U.N. Comm'n on Human Rights, U.N. Doc. E/CN.4/1997/74 (27 Mar. 1997).

15. Bayefsky, supra note 3 at i-ii; Future of UN Treaty Monitoring, supra note 2. 
percent) had between one and five periodic reports overdue. ${ }^{16}$ Submitted reports vary considerably in their structure, content, and quality. ${ }^{17} \mathrm{Com}-$ mittees have adopted guidelines on the form and content of reports, ${ }^{18}$ but many states do not always follow them. Moreover, it is debatable whether governments even take the report drafting process seriously. ${ }^{19}$ Compounding these issues, as more states have ratified the major treaties, committees' workloads have expanded without a corresponding increase in resources or meeting times. ${ }^{20}$

For some, the dismal reporting record merely reflects the primary weakness of the human rights regime-an absence of incentives for states to police compliance. ${ }^{21}$ As states have little to no incentive to report, spotty reporting is unsurprising. More cynically, the system provides few inducements to report thoroughly: states may selectively provide requested information, present information in a way that obscures the situation on the ground, or ignore concerns or questions posed by the treaty body. ${ }^{22}$ For instance, governments, such as the U.S., often fill their reports with long extracts from legislation and formal polices, rather than concrete practices. ${ }^{23}$ Exacerbating the voluntary nature of self-reporting, committee members have limited means to independently verify the information provided, a fact that government officials presumably realize. ${ }^{24}$

16. Report of the Committee against Torture, U.N. GAOR, 66th Sess., at 288-98, U.N. Doc. A/66/44 (2011). The number of parties with overdue reports includes those instances where the Committee has indicated in its concluding observations on the prior report that a revised date of submission (usually in the near future) is permitted. This represents one way in which the Committee attempts to address both systematic late reporting and its own increased workload, deviating from the periodicity mandated in the Convention.

17. Concept Paper on the High Commissioner's Proposal for a Unified Standing Treaty Body: Report by the Secretariat, U.N. International Human Rights Instruments, 5th mtg., at 10 U.N. Doc. HRI/MC/2006/2 (22 Mar. 2006).

18. Compilation of Guidelines on the Form and Content of Reports to be Submitted by States Parties to the International Human Rights Treaties, U.N. International Human Rights Instruments, at 10, U.N. Doc. HRI/GEN/2/Rev.6 (3 June 2009) [hereinafter Compilation of Guidelines]. This document is revised regularly.

19. BAYEFSKY, supra note 3 at $i$-ii; Yoram Dinstein, Human Rights: Implementation Through the UN System, 89 Proceedings Am. Soc. Int'L L. 242 (1995).

20. Future of UN Treaty Monitoring, supra note 2, at 6-7; Michael O'Flaherty \& Claire O'Brien, Reform of UN Human Rights Treaty Monitoring Bodies: A Critique of the Concept Paper on the High Commissioner's Proposal for a Unified Standing Treaty Body, 7 Hum. RTs. L.Rev. 141, 142 (2007).

21. Oona A. Hathaway, Do Human Rights Treaties Make a Difference?, 111 Yale L.J. 1935, 1938 (2002).

22. Anne F. Bayefsky, Making the Human Rights Treaties Work: The Human Rights Agenda for the Twenty-First Century, in Human RiGHTS: An AGENDA FOR THE NEXT CENTURY 229, 239 (John Lawrence Hargrove \& Louis Henkin eds., 1994); Dinstein, supra note 19, at 244.

23. Kenneth Roth, The Charade of US Ratification of International Human Rights Treaties, 1 CHI. J. INT'L L. 347 (2000).

24. Hathaway, supra note 21. 
Furthermore, critics assert that the individuals and groups most affected by treaty violations - and thus most likely to exert pressure on delinquent or non-compliant states-are rarely aware of the reporting process or the content of state reports. Other government or civil society actors are poorly informed because the process of reporting is conducted away from domestic media and nongovernmental organization (NGO) attention. Reports are not widely publicized or disseminated. Critics also point to inadequate qualifications of some committee members, resource and staff constraints, absence of specialization and expertise, and a limited amount of time to engage in a meaningful dialogue as serious impediments to the process. ${ }^{25}$

In contrast to such negative assessments, others assert that the reporting system generally works well. ${ }^{26}$ The committees themselves and the Office of the High Commissioner for Human Rights (OHCHR) have acknowledged shortcomings and made concerted efforts to reform procedures in order to improve both the quantity and quality of state reports. ${ }^{27}$ In order to independently verify reports, committees increasingly rely on information provided by NGOs, national human rights institutions (NHRIs), or other third parties. ${ }^{28}$ Some reports apparently do attract significant media and NGO attention, ${ }^{29}$ although the level of attention varies considerably across states, reports, and time. According to these more positive assessments, the influence of the reporting process and committee recommendations is diffuse and indirect-NGOs, national courts, opposition parties, or other governments can use reports and the committees' concluding observations to pressure governments. ${ }^{30}$ In fact, the establishment of a reporting mechanism may be one of the primary reasons that rights groups lobby for the drafting or ratification of a treaty in the first place. ${ }^{31}$

25. Bayefsky, Making Human Rights Treaties Work, supra note 22, at 233-234; Future OF UN TREATY MONITORING, supra note 2, at 6-9; O'Flaherty, The Concluding Observations of United Nations, supra note 12, at 37; O'Flaherty \& O'Brien, supra note 20, at 142-43.

26. Felice D. Gaer, A Voice Not an Echo: Universal Periodic Review and the UN Treaty Body System, 7 Hum. Rts. L.Rev. 7 (2007); Future of UN Treaty Monitoring, supra note 2, at 501-525.

27. For the most recent effort to improve the treaty body system, see U.N.GAOR. Res. 68/268, U.N. Doc. A/RES/68/268 (9 Apr. 2014).

28. Rules of Procedure, Rule 63, U.N. GAOR, Comm. Against Torture, 44th Sess., U.N. Doc. CAT/C/3/Rev.6 (13 Aug. 2013). See also U.N. Office of the High Commissioner for Human Rights, Information for Civil Society Organizations and National Human Rights Institutions (NHRIs), available at http://www.ohchr.org/EN/HRBodies/CAT/Pages/ NGOsNHRIs.aspx\#section3.

29. Future of UN Treaty Monitoring, supra note 2, at 505-56.

30. See Sally Engle Merry, Human Rights and Gender Violence: Translating International Law into Local JustiCe (2006).

31. For example, in advocating for a disabilities treaty the National Council on Disability argued it would provide "mechanisms for more effective monitoring, including reporting on the enforcement of the convention by governments and non-governmental organizations, supervision by a body of experts mandated by the convention, and possibly the consideration of individual or group complaints under a mechanism to be created by the 


\section{WHY PARTICIPATE IN CAT PERIODIC REVIEW?}

Despite valid criticisms, the reporting record for the CAT is not negligible. Between the first reporting cycle in 1988 and January 2012, the CmAT received 313 of the 506 initial and periodic reports due. ${ }^{32}$ By agreement with the Committee, twenty-three of the reports due (for twenty-two separate countries) were eventually rolled into combined reports or provided partial information, leaving 170 reports not submitted as required.

For those reports eventually received, very few were submitted on time. During the first round of reports due to the CmAT in June of 1988, Sweden was the first country to submit a report, and in fact, did so two days early.3. Eleven out of fifteen countries with reports due in 1988 submitted them that same year. But only nineteen reports (6 percent of all reports submitted) have been received on or before their deadlines, with an additional 107 reports received within the year. Sixty-five reports-20.8 percent of all reports received-were submitted more than five years late. The Committee has adjusted to the reality that many states are not able, or willing, to keep up with their reporting much less to meet "deadlines." Over time, by agreement between the state and the Committee, reports have been consolidated, which may ultimately help to reduce delay and contribute to higher quality (but fewer) submissions.

While the average delay in report submission has increased over time (see Figure 1), states are eventually (often after years of delay) submitting their initial reports and becoming better about submitting subsequent reports, albeit late. The CAT's reporting record demonstrates clear differences across regions, with European countries having higher rates of reporting and meeting deadlines. Countries in Africa (excluding North Africa) and South Asia have the poorest record for both submission and timeliness (see Figure 2).

Despite nonreporting and delay, scores of states have submitted hundreds of reports on the implementation of the torture prohibition. However, why

convention." National Council on Disability, Understanding the Role of an International Convention on the Human Rights of Peoples with Disabilities: A White Paper (2002), available at http://www.ncd.gov/publications/2002/May232002.

32. This article's analysis is based on original panel data (1977-2011) for every state party to the Convention against Torture. Every report submitted to the Committee against Torture was collected, along with descriptive information on submission and due dates, consideration by the Committee and concluding observations. Information on reporting deadlines and submission dates is taken from the reports themselves and the United Nations Treaty Database, specifically information on the reporting cycles, available at http://tbinternet.ohchr.org/_layouts/TreatyBodyExternal/countries.aspx. See also Anne Bayefsky's website on The United Nations Human Rights Treaties, available at http:// www.bayefsky.com/; Section IV, infra, for further information on the coding scheme for report quality.

33. Consideration of reports submitted by States Parties Under Article 19 of the Convention: Sweden, Comm. Against Torture, 44th Sess., U.N. Doc. CAT/C/5/Add.1 (1988). 


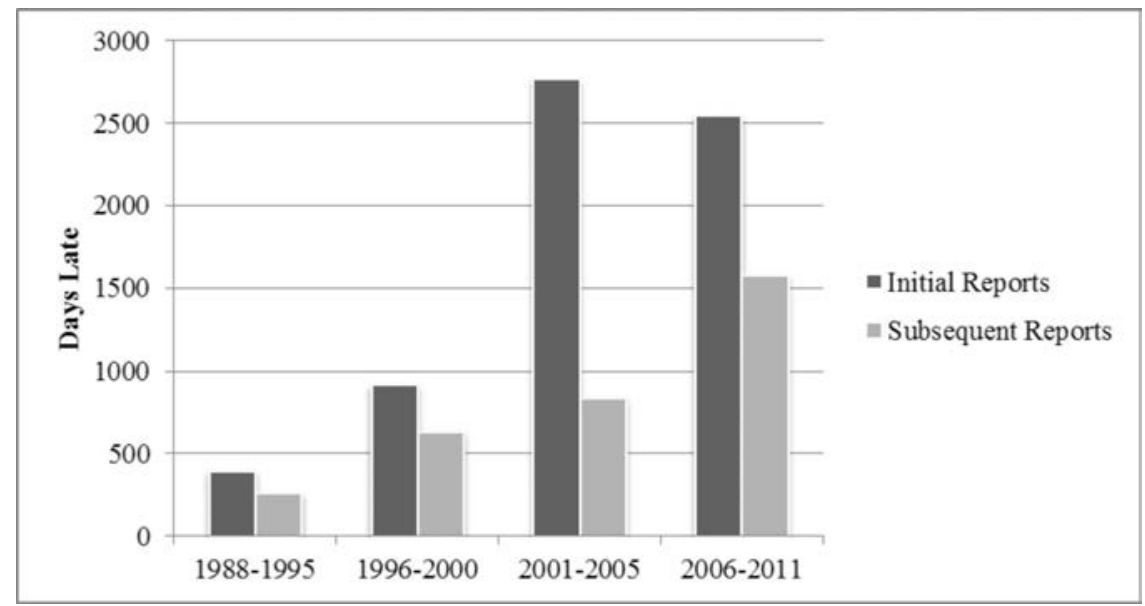

Figure 1—Delays in Reporting to the CAT Committee: 1988-2011

Source: Authors' dataset, compiled from http://www.bayefsky.com/ and verified with information acquired from http://treatybodyreport.org/ and http://www.ohchr.org.

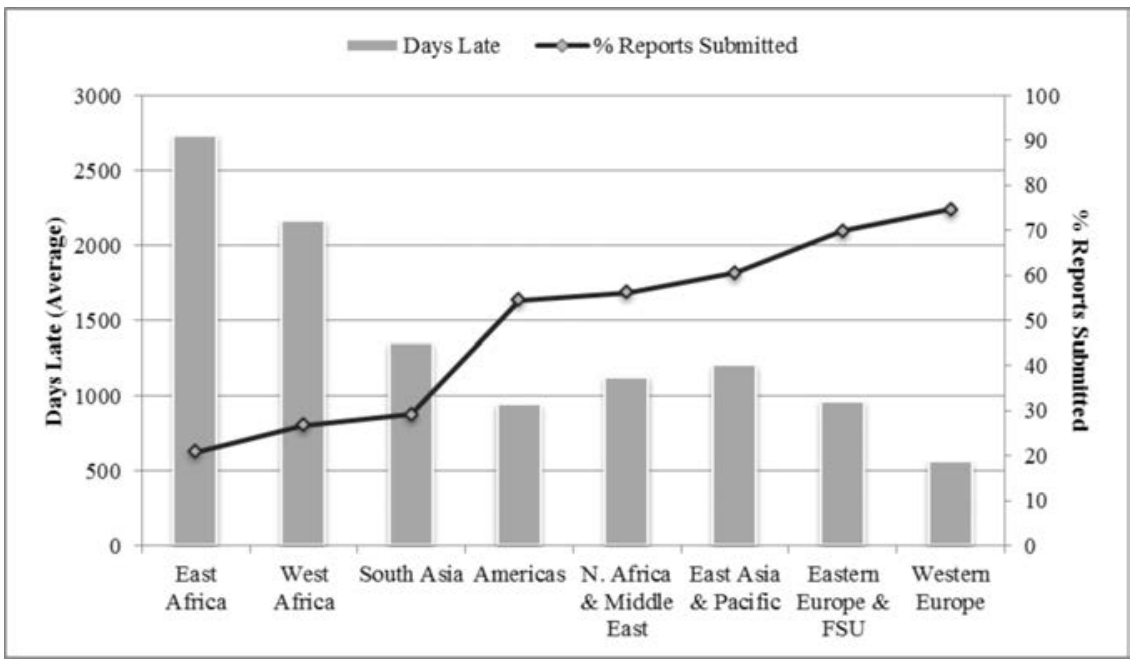

Figure 2-CAT Reporting Record, by Region

Source: Authors' dataset, compiled from http://www.bayefsky.com/ and verified with information acquired from http://treatybodyreport.org/ and http://www.ohchr.org. 
would any government exert the time, energy, and resources to monitor and to report on the implementation of and compliance with a human rights convention, if reporting is meaningless? Even if a government did go through the bureaucratic motions of submitting a report, why would it submit a thorough and responsive report as opposed to whitewashing noncompliant practices or unreflectively cutting-and-pasting laws and policies? A capacity to report might be a necessary condition. However, an underlying commitment to human rights compliance, normative pressures from external actors, and domestic political pressures to "come clean" are also likely to increase the willingness of a state to comply with their reporting obligations in a comprehensive and timely manner.

\section{A. Capacity to Report}

One reason for the variance in reporting may simply be state bureaucratic capacity. While some researchers do not believe that self-reporting on laws and policies requires overly prohibitive resources, ${ }^{34}$ others view capacity constraints as a major reason for temporary non-compliance with international legal obligations generally. ${ }^{35}$ This observation may apply to procedural compliance as well. The treaty committees, states, and the OHCHR all recognize that thorough reporting imposes a burden on states and that insufficient resources represent "significant barriers" to procedural compliance. ${ }^{36}$ Financial, human, institutional, and legal resource constraints could all limit the capacity of a state to report. This article focuses on financial and institutional resources.

For many states, the costs of reporting regularly and thoroughly are not negligible relative to their available resources. While the cost of simply compiling legislation may not be overly prohibitive, monitoring and collecting comprehensive data on torture practices is costly. Information collection systems and dedicated personnel must be put in place and startup requires resources. Providing up-to-date information every four years requires ongoing data collection, verification, and analysis. On average, we would expect wealthier states to be able to report more often. Wealthier states should also be able to provide more information about shortcomings in compliance, which requires collection of comprehensive data on concrete practices.

34. Mitchell, supra note 2, at 118.

35. Abram Chayes \& Antonia Handler Chayes, On Compliance, 47 INT'L Org. 175, 188 (1993).

36. Francoise J. Hampson, An Overview of the Reform of the UN Human Rights Machinery, 7 Hum. Rts. L. Rev. 7, 12 (2007); Hanna Beate Schöpp-Schilling, Treaty Body Reform: The Case of the Committee on the Elimination of Discrimination Against Women, 7 Hum. Rts. L.Rev. 201, 203 (2007). 
Because the collection of information on state practices demands more resources than the mere compilation of legislation, wealthier states possess a higher capacity to be forthcoming about compliance shortcomings within their reports.

Second, quality reporting requires an institutional capacity that can provide factual knowledge of, expertise in, and familiarity with the treaty regime and the reporting process. Some states develop this capacity through their NHRIs, independent governmental bodies specifically mandated to promote human rights. The intended role of NHRIs within the periodic review process is two-fold-both as a source of institutional capacity and, for independent NHRIs, a form of domestic pressure on the government to report. Under the 1991 Principles Relating to the Status and Functioning of National Institutions (the Paris Principles), NHRIs have a responsibility to "contribute to the reports which States are required to submit to United Nations bodies and committees." 37 Additionally, most NHRIs are mandated to advise governments on the compatibility of proposed or existing legislation with international standards. NHRIs apply international standards in their monitoring activities and provide important sources of information regarding states' periodic reports. ${ }^{38}$ More recently, the OHCHR further encourages NHRIs to "contribute to the State parties reports, including through consultation and comments to the State official report," ${ }^{39}$ to encourage governments to comply with their reporting obligations in a timely manner, to submit their own "shadow reports," and otherwise provide information on implementation to the treaty bodies. ${ }^{40}$

An institutional capacity hypothesis leads us to expect a relatively more robust reporting record by states with NHRIs than by those without. In addition, countries that have decided to create an NHRI are likely more committed to the international human rights system, and thus the presence of an NHRI may also capture a state's human rights preferences.

37. National Institutions for the Promotion and Protection of Human Rights, Annex: Principles Relating to the Status of National Institutions, U.N. GAOR Res. 48/134, I 3(d), U.N. Doc. A/RES/48/134 (20 Dec. 1993).

38. On the role of NHRI's information provision and transparency-enhancing functions, see Cosette Creamer \& Beth A. Simmons, Transparency at Home: How Well do Governments Share Human Rights Information with Citizens?, in Transparency IN INTERnational Law (Andrea Bianchi \& Anne Peters eds., 2013).

39. U.N. Office of the United Nations High Commissioner for Human Rights, "Information Note: National Human Rights Institutions (NHRIs) interaction with the UN Treaty Body System" (5 Apr. 2011), available at http://nhri.ohchr.org/EN/IHRS/TreatyBodies/Page\%20 Documents/NHRIs\%20and\%20the\%20Treaty\%20Bodies.Infonote.11.4.2011.doc.

40. Richard Carver, A New Answer to an Old Question: National Human Rights Institutions and the Domestication of International Law, 10 Hum. RTs. L. Rev. 1 (2010). 


\section{B. Human Rights Commitment}

Many countries do comply with most of their treaty obligations, and even more genuinely want to comply. Moreover, many want to be viewed as strong supporters of international human rights law. Faithful reporting is one way to signal commitment. Because it is not easy to monitor all instances of noncompliance, treaty ratification itself serves as a pooling equilibrium, in that it provides no indication of who is in fact complying. Reporting, however, potentially serves as a separating equilibrium, distinguishing regime supporters and compliers from noncompliers, as it is relatively more costly (see above) than ratification alone. Monitoring represents one tool to detect violations..$^{41}$ By self-reporting, governments can draw attention to their compliant policies and practices, thereby gaining additional reputational benefits for their efforts. ${ }^{42}$ Even "good faith" noncompliers-for example, those facing serious capacity constraints ${ }^{43}$ — may view reporting as reaffirming their commitment to regime goals. On average then, we would expect states with a better human rights record to regularly comply with their reporting obligations. On the other hand, parties that have exerted little or no effort to implement or comply with a treaty would likely refrain from submitting reports, either because they seek to undermine regime progress or because they have no incentive to report. ${ }^{44}$

\section{Imitation and Normative Pressure}

Both normative pressure and imitation shape states' decisions to ratify international human rights treaties, ${ }^{45}$ and it is plausible that these mechanisms continue to operate post-ratification with respect to procedural compliance. Governments facing uncertainty about what the international human rights system requires or expects in terms of reporting, may similarly imitate other states' reporting practices. They may not know whether a report is "really required," whether the due date is "hard and fast," or even what constitutes

41. George W. Downs, David M. Rocke \& Peter Barsoom, Is the Good News about Compliance Good News about Cooperation, 50 INT'L OrG. 379 (1996); Jutta Joachim, Bob Reinalda \& Bertjan Verbeek, International Organizations and Implementation: Pieces of the Puzzle, in International Organizations and Implementation, supra note 2, at 9-10.

42. Mitchell, supra note 2, at 117 .

43. Abram Chayes \& Antonia Handler Chayes, The New Sovereignty: Compliance with International Regulatory Agreements 161-162(1995).

44. Schöpp-Schilling, supra note 36, at 204.

45. See Beth A. Simmons, Mobilizing for Human Rights: International Law in Domestic Politics (2009); Christine Min Wotipka \& Kiyoteru Tsutsui, Global Human Rights and State Sovereignty: State Ratification of International Human Rights Treaties, 1965-2001, 23 SOCIOlOGiCAl ForUm 724 (2008). 
an acceptable submission. Moreover, they may not know what the domestic or international repercussions of (not) reporting may be. As long as the overall record within the regime is fairly sparse, nonreporting may not generate social costs because it does not necessarily signal noncompliance with treaty obligations. ${ }^{46}$ However, as more states begin to get their reports in, the pressure to report should increase. This could be for mimetic reasons, if governments pay attention to and seek to imitate what a majority of other parties are doing. It could also be for normative reasons; the social pressures to report increase as reporting becomes viewed as a legitimate and expected practice of CAT members, with governments' reporting decisions particularly influenced by the reporting record of states they especially respect or want to emulate for status reasons. ${ }^{47}$

As the World Society literature emphasizes, governments might also view participation within the CAT as a way of demonstrating they are legitimate members of the regime regardless of whether they have fully implemented or complied with treaty obligations. ${ }^{48}$ This approach stresses the cumulative ability of international institutional commitments to pressure and to persuade recalcitrant governments. If this is accurate, then governments will report more frequently the more deeply they are embedded in the international human rights system. In addition, deeper enmeshment in the international human rights regime increases a country's experience with expectations for self-reporting across human rights treaties, leading to improvements in report quality over time as governments learn "best practices."

\section{Domestic Political Pressure}

The reporting process is likely to be strongly shaped by domestic political needs and pressures. Reporting (and reporting well) sends a signal not only to the international community, but to domestic citizens and politicians as well. Domestic political pressure thus represents one reason why a government might have incentives to report and report well. This pressure could come from domestic rights groups, who often lobby for both increased rights protection and greater transparency in treaty reports, or from political opposition groups or parties. ${ }^{49}$ To be sure, some governments are simply

46. Mitchell, supra note 2, at 118 .

47. Ryan Goodman \& Derek Jinks, How to Influence States: Socialization and International Human Rights Law, 54 Duke L. J. 621 (2004).

48. See generally Martha Finnemore, Norms, Culture, and World Politics: Insights from Sociology's Institutionalism, 50 INT'L OrG. 325 (1996); John Meyer, John Boli, George Thomas \& Francisco Ramirez, World Society and the Nation-State, 103 Am. J. Sociology 148 (1997).

49. On the role of domestic mobilization for human rights protections see SIMmONS, supra note 45. See also Bruce Bueno de Mesquita, George W. Downs, Alastair Smith \& 
unconstrained by domestic groups when it comes to human rights accountability. ${ }^{50}$ In countries with no effective political opposition or where criticism of the government's human rights practices will almost certainly be crushed, there is little domestic incentive for governments to report transparently on their treaty implementation.

The situation is more complex in settings where domestic actors can increase the political costs associated with failure to report or with rendering a whitewashed report. In highly democratic polities with inherently high levels of transparency, providing a report to the CmAT could be seen as redundant and maybe unnecessary. Domestic groups who are confident that domestic political processes are exposing and correcting unacceptable torture practices may not see international oversight as especially important; indeed many such states may have robust legislative oversight on treaty implementation and even state reports. ${ }^{51}$ If this is the case, domestic political demands for external reporting could be muted. For these reasons, there may be no simple linear relationship between traditional measures of democracy and the willingness of a state to report. Where transparent democracies do report, it may have less to do with domestic politics than with providing an example to be emulated, as discussed above.

Matters are even more complex in partial, unstable, or transitioning democracies. On the one hand, a self-critical report could provide damaging information to political opponents of the regime. ${ }^{52}$ If taken seriously, it could spark demands for change that the government is not in fact ready

Feryal M. Cherif, Thinking Inside the Box: A Closer Look at Democracy and Human Rights, 49 INT'L STUD. Q. 439 (2005) (arguing that party competition helps reduce human rights violations).

50. James R. Hollyer \& B. Peter Rosendorff, Do Human Rights Agreements Prolong the Tenure of Autocratic Ratifiers?, 44 N.Y.U. J. INT'L L. \& PoL. 791, 800 (2011-2012).

51. Currently, the International Parliamentary Union (IPU) lists 165 parliamentary bodies in 109 countries with a human rights focus, though only 63 parliamentary bodies in 49 countries specialize in human rights. IPU, PARLINE database, available at http://www. ipu.org/parline-e/instanceadvanced.asp. Not all of these committees have an explicit mandate to monitor treaty implementation, although some do. For example the United Kingdom established the Joint Committee on Human Rights in 2001, comprised of six members each from the House of Commons and the House of Lords. The Joint Committee has interpreted its mandate to include scrutiny of Bills for their human rights compatibility and compliance with human rights treaties, examination of reports made by the UK government under these conventions, and monitoring implementation of the concluding observations of the UN treaty bodies. United Kingdom Joint Committee on Human Rights, The Committee's Future Working Practices: Twenty-Third Report of Session 2005-06 (2006), available at http://www.publications.parliament.uk/pa/jt200506/jtselect/ jtrights/239/239.pdf.

52. On the relationship between democratic institutions, violent dissent, and the use of torture see Courtney Conrad \& Will H. Moore, What Stops the Torture?, 54 Am. J. PoL. Scl. 459 (2010). On the influence of treaty ratification within repressive regimes, see Emilie Hafner-Burton \& Kiyoteru Tsutsui , Justice Lost! The Failure of International Human Rights Law to Matter Where Needed Most, 44 J. Peace Res. 407 (2007). 
to make, unleashing a type of normative "entrapment" associated with "spiraling" demands for change. ${ }^{53}$ If this is the case, transitioning or partial democracies will be less likely to take the political 'risk' of report submission. On the other hand, domestic groups could view reporting as a costly signal of the government's intention to improve its rights practices. Such a report could assuage rather than heighten criticism, thereby giving the government breathing room to implement change at its own pace. If this is the case, then the existence of political opposition should correlate with more timely reports. It should also correlate with higher quality reports, which would send a more costly signal of the government's intentions.

It is likely, however, that new governments will generally be willing to render reports on the practices of their predecessors. They may want to do so to make a clear break with the past, and to distance themselves from the repression of a previous regime. New regimes (particularly democratic ones) are often supported by domestic civil society groups that helped bring them to power, which provides these governments with an enhanced incentive and ability to collect information on the previous regime's torture practices. A report to the CmAT is an excellent (indeed legally required) opportunity for a new government to set the record straight, to assign blame, and to chart a new course for the future. This suggests that reporting timeliness and especially quality should improve shortly after a significant regime change or democratic transition.

\section{E. Findings}

This section describes the variables employed to test these expectations for report submission and the results of a series of multivariate analyses. Table 1 provides further summary statistics for each variable.

The first outcome is Report Submission, a dummy variable for whether a state party submitted a report (for year of submission and year due for those reports never submitted). For the hypothesis relating to government capacity discussed in Section III.A above, GDP per capita (as collected by the World Bank) measures a country's financial capacity to report, while NHRI partly captures its institutional reporting capacity, measured by whether a country had established an NHRI at the time of report submission. Population is included to control for the size of a polity. ${ }^{54}$

A country's Torture Score proxies its human rights practices relevant to the Convention. Governments with worse torture records could be expected

53. Thomas Risse, Stephen C. Ropp \& Kathryn Sikgink, The Power of Human Rights: International Norms and Domestic Change 172, 202 (1999).

54. David L. Cingranelli, David L. Richards \& K. Chad Clay, The CIRI Human Rights Dataset (2013), available at http://www.humanrightsdata.com. 
Table 1. Summary Statistics

\begin{tabular}{|c|c|c|c|c|c|}
\hline Dependent Variables & N & Mean & Standard Deviation & Min & Max \\
\hline Report Submission & 490 & 0.639 & 0.481 & 0 & 1 \\
\hline Quality & 313 & 3.348 & 1.897 & 0 & 6 \\
\hline Responsiveness & 197 & 1.609 & 1.171 & 0 & 3 \\
\hline Explanatory Variables & & Mean & Standard Deviation & Min & $\operatorname{Max}$ \\
\hline GDP per capita (logged) & & 8.247 & 1.610 & 4.760 & 12.059 \\
\hline NHRI & & 0.647 & 0.478 & 0 & 1 \\
\hline Torture Score (CIRI) & & 0.758 & 0.745 & 0 & 2 \\
\hline Article 22 Declaration & & 0.408 & 0.492 & 0 & 1 \\
\hline Regime Reporting Density (\%) & & 59.613 & 9.875 & 0 & 67.925 \\
\hline Regional Reporting Density (\%) & & 55.573 & 23.658 & 0 & 100 \\
\hline Human Rights Treaties (Number) & & 11.218 & 3.723 & 2 & 21 \\
\hline Human Rights Treaties (Proportion) & & 0.488 & 0.163 & 0.090 & 0.910 \\
\hline Polity IV & & 4.484 & 6.229 & -10 & 10 \\
\hline De facto Political Opposition & & 1.906 & 0.394 & 0 & 2 \\
\hline Newly Transitioned Democracy & & 0.287 & 0.453 & 0 & 1 \\
\hline Political Transition (1 year) & & 0.034 & 0.182 & 0 & 1 \\
\hline Political Transition (2 years) & & 0.060 & 0.238 & 0 & 1 \\
\hline Population (logged) & & 15.876 & 1.889 & 10.327 & 20.994 \\
\hline
\end{tabular}

to refrain from submitting reports to conceal this fact or to submit obscure reports when they do. This indicator is measured using the CingranelliRichards (CIRI) Human Rights Database's torture score and coded as " 0 " for torture practiced frequently, " 1 " for torture practiced occasionally, and " 2 " for torture not practiced or unreported in a given year. ${ }^{55}$ Article 22 Declaration identifies states that have accepted the jurisdiction of the CmAT, under Article 22 of the CAT, to receive individual complaints as an additional proxy for human rights commitment. Governments genuinely committed to the regime should be more likely to provide individuals a right to submit complaints to the Committee directly, and thus more likely to report. ${ }^{56}$

Reporting density within the CAT regime, measured by cumulative submitted reports as a percentage of total reports due, provides an indication of the degree of social pressure to report. There are two important referent groups: the states parties to the CAT and countries with which a government identifies, typically understood as neighboring countries. ${ }^{57}$ If states operate in conformity with an imitation logic, we would expect their reporting

55. Id. For a detailed discussion of the CIRI Human Rights Dataset and an evaluation of its scale, see Ann Marie Clark \& Kathryn Sikkink, Information Effects and Human Rights Data: Is the Good News about Increased Human Rights Information Bad News for Human Rights Measures?, 35 Hum. RTs. Q. 539 (2013).

56. The status of CAT, art. 22 Declarations can be found in the United Nations Treaty Collection, available at https://treaties.un.org/Pages/ViewDetails.aspx?src=TREATY\&mtdsg $n o=I V-9 \&$ chapter $=4 \&$ lang $=e n$.

57. Wotipka \& Tsutsui, supra note 45. 
records to be correlated with the density of reporting in the regime more generally (Regime Reporting Density) as well as with the density of reporting in a state's region (Regional Reporting Density). Human Rights Treaties (Number Ratified) measures the number of core international human rights treaties ratified by a state as a proxy for how embedded a country is within the international human rights system, and thus the extent of normative pressure to report it experiences.

Five measures of domestic political pressure are employed within separate model specifications. First, although regime type (Polity IV score) represents a crude proxy for the presence of domestic political pressure, more democratic countries typically provide greater civil liberties and media freedom, facilitating the ability of domestic rights groups to pressure the government to comply with its reporting obligations ${ }^{58}$ In addition, in strong democracies with institutionalized political opposition, governments may face greater pressure to report and submitted reports should be of higher quality because there are independent checks on information provided. In highly autocratic countries, on the other hand, a government would not need to report for domestic reasons.

Second, the variable De facto Political Opposition measures the existence of political parties within a country, coded " 0 " for no parties, " 1 " for one political party, and "2" for multiple parties. ${ }^{59}$ This variable provides insight into the extent to which a government might use the treaty monitoring process to placate or neutralize internal political opposition. Finally, as discussed previously, new democracies or regimes recently experiencing a political transition may have different incentives to report than established regimes. To capture this, the variable Newly Transitioned Democracy indicates those countries that have fallen both above and below 7 on the Polity IV scale since World War II or independence, but score above 7 the year a report is due or submitted (a standard threshold for democratic government). The Political Transition variable measures the extent to which a country has experienced a democratizing change in the past one to three years (an increase of +3 or more points on the Polity IV scale) ${ }^{60}$

Table 2 reports the results of a series of multivariate analyses. Across all three model specifications, there is strong evidence that regional-level

58. Monty G. Marshall, Ted Robert Gurr \& Keith Jaggers, Polity IV Project: Political Regime Characteristics and Transitions, 1800-2012, available at http://www.systemicpeace.org/ polity/polity 4.htm.

59. José Antonio Cheibub, Jennifer Gandhi, \& James Raymond Vreeland, Democracy and Dictatorship Revisited, 143 Рчв. CHOICE 75-76, 80 (2010).

60. Polity IV adopts a threshold value of a 3-point change in the POLITY variable to define a regime transition. See Monty G. Marshall, Ted Robert Gurr \& Keith Jaggers, Polity IV Project: Political Regime Characteristics and Transitions, 1800-2012-Dataset Users' Manual 30 (2012). 
Table 2. Reporting to the Committee Against Torture

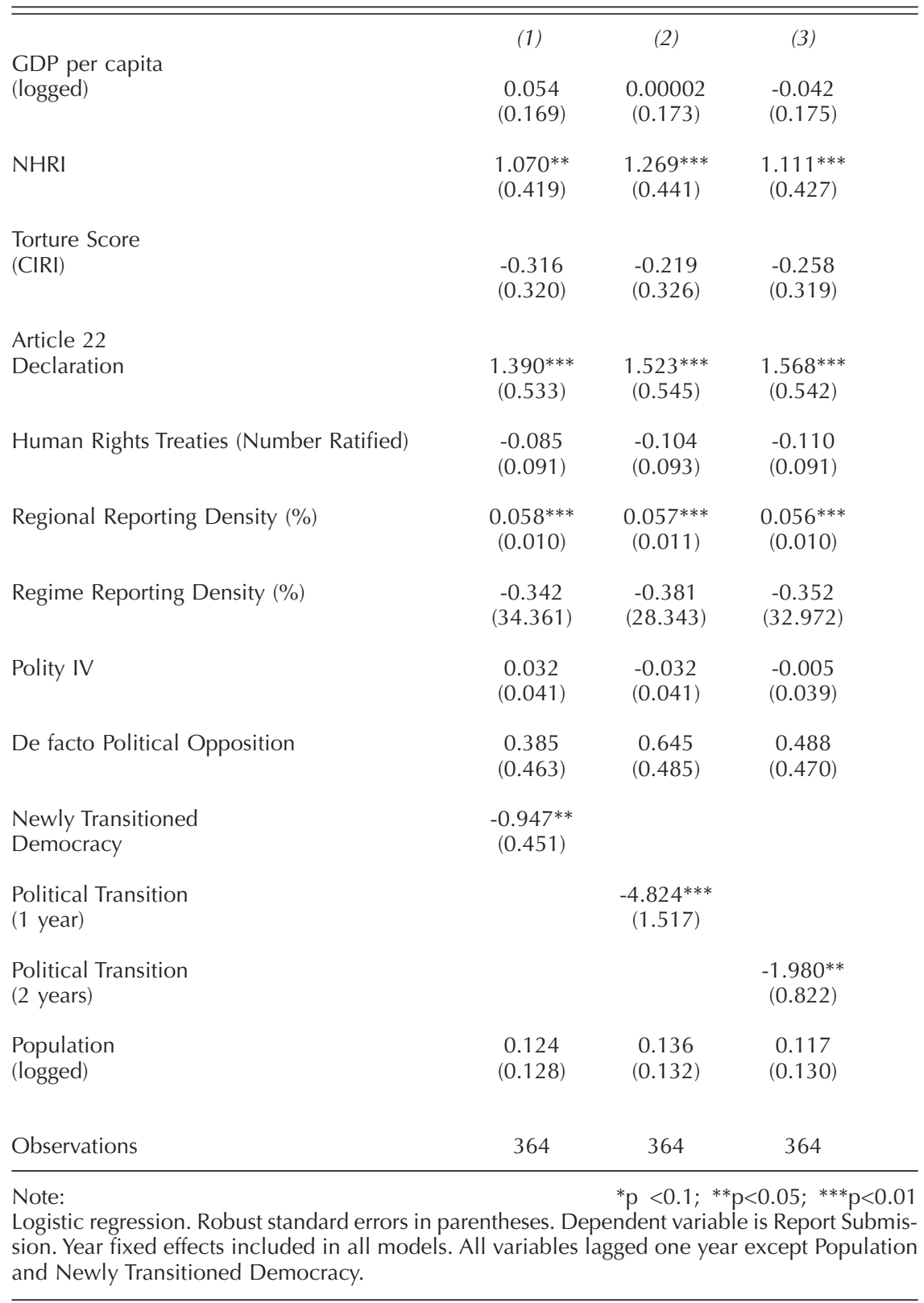


imitation operates within the CAT regime. Reporting density within a state party's region-though not within the regime as a whole-substantially increases a government's probability of reporting. To be sure, within the past decade the CAT Committee and the OHCHR have made considerable efforts to improve the reporting record of the CAT regime. Still, it is entirely plausible that there is also a mimetic effect-as more neighboring states engage with the CAT regime, the expectation that governments should take their reporting obligations seriously increases.

The existence of an NHRI also demonstrates a consistent and prominent influence on the probability of reporting. The presence of an NHRI may simply reflect a government's commitment to protecting human rights. However, an $\mathrm{NHRI}$ could also contribute to report submission by providing institutional expertise and capacity, or by increasing the amount of domestic pressure on a government to report. While it is difficult to empirically disentangle these mechanisms, the strong association between the presence of an NHRI and report submission supports the OHCHR's recent efforts to integrate NHRIs within the human rights treaty monitoring process. Financial capacity (GDP per capita), on the other hand, does not seem to increase the probability of report submission, suggesting that this is probably not a sufficiently precise indicator for "capacity" with respect to human rights reporting.

With respect to preferences, the probability of submitting a report increases significantly for governments that have made Article 22 declarations. Given that a serious commitment to the CAT regime often motivates governments to accept the jurisdiction of the Committee over individual communications, it is not surprising that these governments are also more likely to submit state reports to the treaty body. In contrast, the torture practices of a country (Torture Score (CIRI)) do not seem to influence a government's decision to report. States in which there have been no reported incidents of torture in a given year are not any more or less likely to submit their reports than states with widespread reported torture incidents.

Similarly, embeddedness within the international human rights system (Human Rights Treaties (Number Ratified)) does not influence the probability of report submission. This is somewhat surprising, as countries that agree to a large number of human rights treaties could be expected to fulfill obligations contained therein (including that of reporting). It is consistent, however, with "reporting fatigue" within the international human rights system. When governments face multiple reporting obligations across human rights conventions, they may be less able and willing to keep up with their reporting obligations for each. ${ }^{61}$

61. Many governments must also provide information on implementation of the prohibition against torture in the context of reporting under the International Covenant on Civil and Political Rights. Given this partly overlapping procedural obligation, states may simply prioritize reporting to the Human Rights Committee over the specialized purview of the CmAT. 
Finally, the domestic political characteristics of a country, as measured by a government's level of democracy (Polity $I V$ ) and the existence of political parties (De facto Political Opposition), do not seem to influence the likelihood of a government complying with its reporting obligations. Countries that have recently transitioned to democracy, on the other hand, have a much lower probability of submitting their reports compared to stable democracies or stable autocracies. The significant negative coefficient for Newly Transitioned Democracy suggests that new democratic governments may be less willing to immediately render reports on their country's torture practices. Similarly, governments that have undergone a democratizing transition within the past two years (Political Transition) have a much lower probability of submitting their CAT reports when due, as compared to countries that have not experienced a transition (stable regimes or countries that have moved in an anti-democratic direction). This tentatively suggests that right around the time of political transitions, governments are much more wary of the potential consequences of rendering reports on torture practices. It could also suggest that such regimes simply do not place a high priority on fulfilling their CAT reporting obligations during and immediately following the transition period. However, when newly democratizing countries do report, the quality of their reports are exceptionally high, as discussed in the next section.

\section{CONSTRUCTIVE ENGAGEMENT WITH THE CAT REGIME}

While the very fact of reporting may provide an opening for constructive engagement with the treaty monitoring body, the review process can only be expected to be effective if governments take it seriously. Under what conditions will states actually submit high quality reports? Here, "high quality" means the provision of information about: progress made in implementation of and compliance with treaty provisions; recognition of shortcomings or deficiencies in implementation and compliance; acceptance of and thorough responses to committee recommendations; and data meaningful to treaty provisions and compliance outcomes. The most transparent and highest quality reports are those that not only systematically acknowledge shortcomings, but also propose specific and concrete steps to remedy them, as opposed to attempting to justify such shortcomings.

To capture report quality, we coded every submitted report along four dimensions: implementation, compliance, responsiveness, and data. Treaty bodies have requested that state reports include information on changes in law and administrative procedures (Implementation) and concrete practices on the ground relevant to treaty obligations (Compliance). Most have expressly requested statistical information on outcomes relevant to treaty 
obligations (Data). ${ }^{62}$ "Constructive dialogue" implies responsiveness; therefore every subsequent periodic report was coded for how responsive a country was to the Committee's concluding observations on their previous report (Responsiveness). Figure 3 provides an overview of the instrument used to code each report to the CmAT along these four dimensions.

\section{Implementation}

\section{REPORT QUALITY}

$>0=$ only positive information about laws, policies and programs relevant to treaty obligations

$>1=$ mostly positive information about laws, policies and programs relevant to treaty obligations

$>2$ = positive information, but explicitly and fairly systematically acknowledges shortcomings in implementation

\section{Compliance}

$>0=$ no mention of compliance

$>1=$ includes only positive information about compliance outcomes relevant to treaty obligations

$>2$ = mostly positive information about compliance outcomes relevant to treaty, some discussion of shortcomings and future goals

$>3$ = positive information, but explicitly acknowledges shortcomings in compliance outcomes relevant to treaty obligations

Data

$>0=$ report does not provide meaningful data/statistics (information about outcomes relevant to treaty obligations)

$>1$ = report does provide meaningful data/statistics (information about outcomes relevant to treaty obligations)

\section{REPORT RESPONSIVENESS}

$>0=$ does not acknowledge or respond to any concerns of the treaty body or only makes passing reference to committee concerns and provides vague response

$>1$ = responds to questions posed by the treaty body (largely related to requests for information)

$>2$ = acknowledges some concerns of the treaty body regarding compliance, but largely justifies current policies and efforts

$>3$ = extensively acknowledges concerns of the treaty body and develops programs and approaches to meet concerns

Figure 3. Coding Scheme for CAT Report Quality and Responsiveness

62. Alston, supra note 14 , at 22 . 
These measures of report quality do not reflect the extent to which a government actually implements and complies with CAT obligations. Rather, a report's Implementation and Compliance scores measure the extent to which a government is transparent and forthcoming about ways in which it may fall short-however minimally, such as not providing sufficient food to prisoners or training to police officers-with respect to treaty obligations. It also reflects the extent to which a government, within its report, attempts to provide detailed proposals to address these shortcomings. Governments that largely fulfill CAT obligations may not have many implementation shortcomings in particular to reveal, though improvement is always possible. To account for this, report quality was measured based on a combination of both quantity and thoroughness of shortcoming acknowledgments.

The reports that score low (0) on Implementation do not explicitly identify deficiencies in a government's existing legislation, administrative regulations, or legal institutions relevant to the state's CAT obligations. Many reports only briefly mentioned that existing laws do not include a definition of torture; these reports also received a score of (0) on the Implementation scale. In contrast, a report received an Implementation score of (1) if: it acknowledges the absence of a definition of torture and thoroughly discusses this deficiency, it acknowledges other areas under the CAT for which the government still lacks sufficient legislation (largely in the area of nonrefoulement obligations under CAT Article 3), ${ }^{63}$ or it recognizes that internal domestic or regional institutions (such as the European Committee for the Prevention of Torture and Inhuman or Degrading Treatment or Punishment ${ }^{64}$ have criticized the government's legislation for providing insufficient protections. Finally, reports that score high (2) on the Implementation scale are those that systematically acknowledge shortcomings in legislation. In addition, these reports discuss proposed or ongoing changes to address these deficiencies (i.e. legislative amendments proposed or a new bill drafted). For each report, these actions on addressing shortcomings must have occurred since the previous report's submission, be ongoing, or represent proposed plans for future action.

The reports that score low (0) on the Compliance measure contain no discussion or information about treaty relevant outcomes or concrete practices on the ground (as compared to the focus on laws and regulations for Implementation). Reports that score a (1) on Compliance provide primarily positive or neutral information about concrete practices, such as prison conditions, and may include references to individual cases of CAT violations. For a report to score a (2) on Compliance it must not only present information about shortcomings, but also explicitly acknowledge these outcomes as

63. CAT, supra note 4 , art. 3 .

64. European Convention for the Prevention of Torture and Inhuman or Degrading Treatment or Punishment, E.T.S. 126, entered into force 1 Feb. 1989, available at http://www1. umn.edu/humanrts/euro/z34eurotort.html. 
problematic. These reports often point to specific difficulties or challenges faced by the country as reasons for non-compliance (i.e. lack of capacity or economic resources). Reports that score high (3) on Compliance provide a systematic discussion of shortcomings and, as with Implementation, outline proposed actions to address deficiencies. However, the focus here is on changing practices or outcomes (such as training more judges or police officers, or adjusting prisoners' diets) rather than legislation. Actions to address shortcomings must have occurred since the previous report's submission, be ongoing, or represent proposed plans for future action.

A report's score on Responsiveness measures the extent to which a government acknowledges the CmAT's recommendations to address identified shortcomings (again, however minimal) and responds with a relatively detailed proposal to do so. In this respect, a report's Responsiveness score proxies the extent to which a government engages in a dialogue with the treaty body. For this reason, a state party's first report does not receive a Responsiveness score; only subsequent reports can potentially respond to the Committee's concluding observations on previous reports. Reports that score low (0) on Responsiveness do not acknowledge any treaty body concerns or only make passing reference to the Committee's concluding observations. Reports that answer questions raised by the Committee-either through their concluding observations or through requests for additional information conveyed to the party prior to report submission-receive a score of (1) if the response provides information without mentioning actions to address the issue raised. Reports that address some of the Committee's concerns but explain why the status quo satisfies these recommendations or rejects the concern on other grounds receive a score of (2). These reports largely justify current policies and efforts in relation to a substantial proportion of the recommendations addressed. Reports that score high (3) on Responsiveness may still include some justifications for the status quo, but also outline concrete efforts or actions taken or proposed to address the majority of the Committee's concerns and recommendations.

Finally, each report received a dichotomous Data score based on whether it included meaningful data and statistics, defined as information relevant to treaty obligations. Reports that only include data on country demographics or socioeconomic variables received a score of (0), while those that include at the very least one set of relevant statistics received a score of (1). In sum, each initial report can potentially receive an aggregate Quality score ranging from 0 (low quality) to 6 (high quality), while subsequent reports can potentially receive an aggregate Quality and Responsiveness score ranging from 0 (low quality and responsiveness) to 9 (high quality and responsiveness).

The quality and responsiveness of reports improves both over time and with the report number (see Figures 4 and 5), indicating that as states report more, their reports improve on average. This could be indicative of 


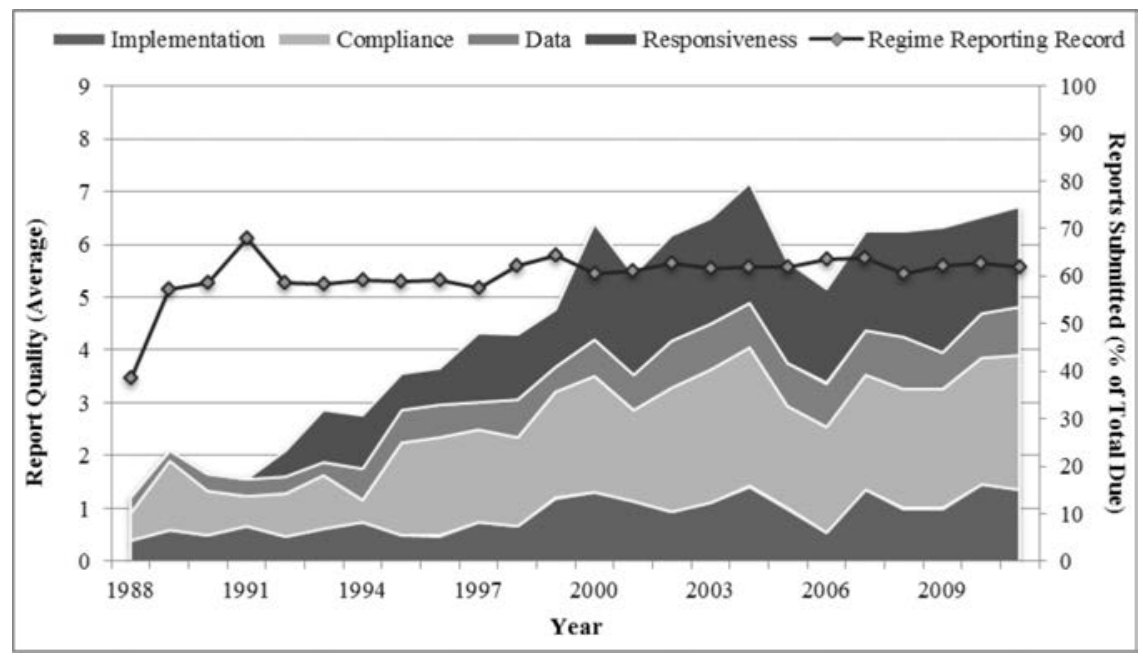

Figure 4-Aggregate Report Quality, by Year

Source: Authors' dataset, based on coding all submitted state reports along dimensions of Implementation, Compliance, Responsiveness and Data. Aggregate quality score ranges from 0 (not transparent, forthcoming or responsive) to 9 (highly transparent, forthcoming and responsive).

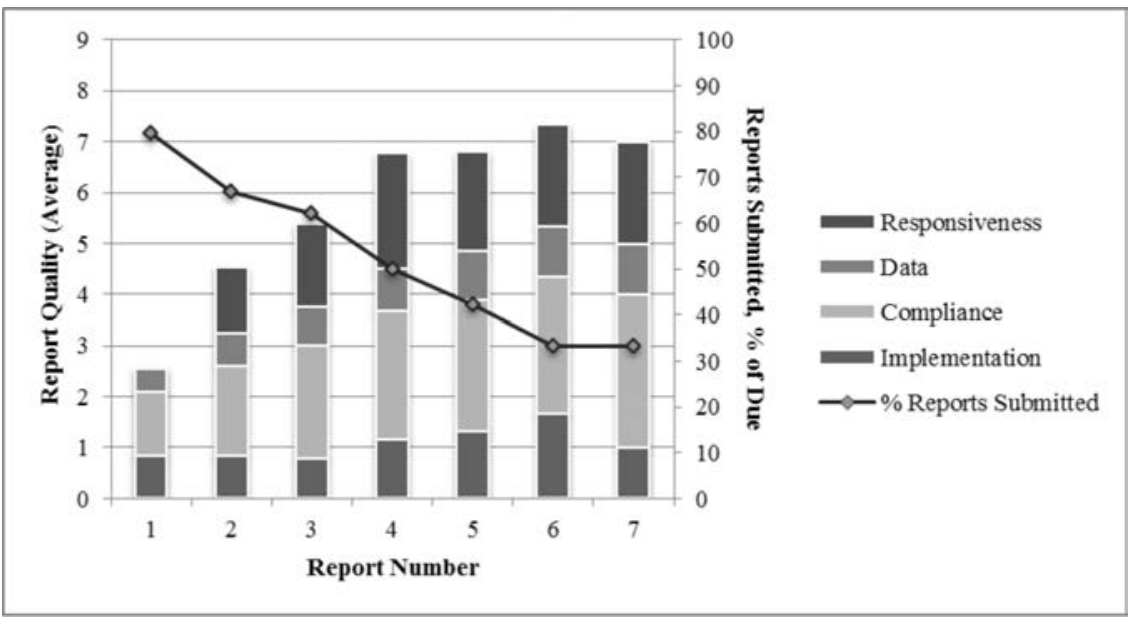

Figure 5-Aggregate Report Quality, by Report Number

Source: Authors' dataset, based on coding all submitted state reports along dimensions of Implementation, Compliance, Responsiveness and Data. Aggregate quality score for initial reports (Report Number 1) ranges from 0 (not transparent or forthcoming) to 6 (highly transparent and forthcoming). Aggregate quality score for subsequent reports (Report Numbers 2-7) ranges from 0 (not transparent, forthcoming or responsive) to 9 (highly transparent, forthcoming and responsive). 
increased engagement or learning about what the international bureaucracy wants to hear. But it could also be the result of selection-only the most sincere countries submit multiple reports and the higher quality scores actually represent fewer total reports. In addition, the CmAT has increased their specific recommendations in their concluding observations in recent years, as opposed to vague expressions of concern characteristic of early responses. This change in format could also account for the secular improvement in report quality and responsiveness over time.

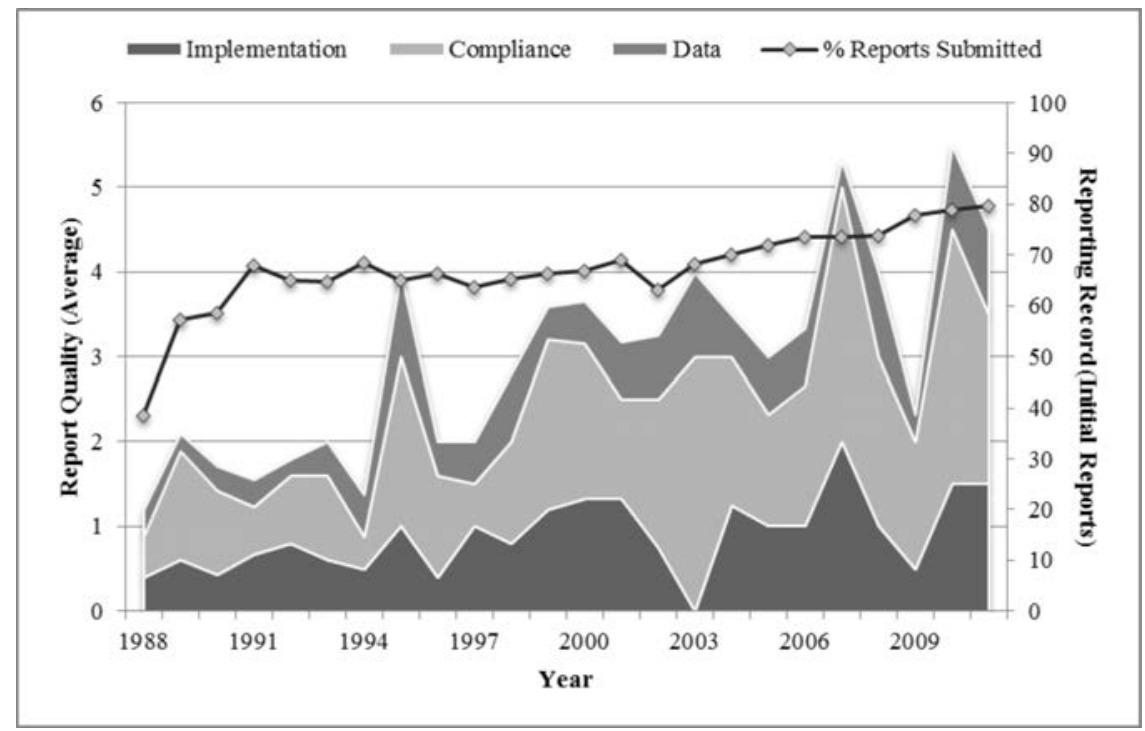

Figure 6-Initial Reports: Aggregate Average Report Quality, By Year

Source: Authors' dataset, based on coding all submitted state reports along dimensions of Implementation, Compliance, Responsiveness and Data. Aggregate quality score for initial reports ranges from 0 (not transparent or forthcoming) to 6 (highly transparent and forthcoming).

Are states learning how to submit higher quality reports simply from their own experience, or are they learning from observing other countries' reports and interactions with the CmAT? With respect to initial reports, mimetic learning is apparently occurring, as the average quality of first reports submitted within the past decade is considerably higher than that of initial reports submitted in the early years of the CAT regime (see Figure 6). This could be due to the fact that in 2004 the OHCHR and the treaty bodies adopted a set of "Harmonized Guidelines on Reporting under the International Human Rights Treaties," with the aim of clarifying the appro- 
priate form and content of state party reports. ${ }^{65}$ While the average quality of initial and subsequent reports has slightly increased since the adoption of these Harmonized Guidelines, these guidelines alone cannot account for the noticeable improvement in report quality between 1994 and 2004.

In theory, wealthier countries possess the financial resources to be able to report more thoroughly, as comprehensive information and data on concrete practices is relatively more costly to collect than information on legislation alone. However, there does not appear to be significant descriptive variation across income levels in either the overall Quality of a report (combined scores on Implementation, Compliance and Data) or in Responsiveness. With respect to institutional capacity, countries that have established NHRIs by the time of submission do seem to provide higher quality reports on average, for both initial and subsequent reports, than countries without NHRIs. The presence of an NHRI is associated with an increase in aggregate report Quality of 1.066 (independent t-test, $p<.001$ ) and in Responsiveness of 0.474 (independent t-test, $p<.001$ ), suggesting that institutional capacity plays an important role in quality and responsive reporting.

Tables 3 and 4 present the results of a series of multivariate analyses separately examining the factors correlated with report Quality and Responsiveness. Neither financial capacity (GDP per capita) nor the existence of an NHRI appears to increase a state's probability of submitting a higher quality report, controlling for other factors. However, the presence of an NHRI does significantly increase the probability of a government being more responsive to Committee concerns or recommendations, suggesting that either institutional capacity or this additional domestic pressure improves a government's dialogue with the CmAT.

Governments with treaty-compliant practices and policies were hypothesized to be more likely to submit a thorough report than countries that engage in torture, in order to draw attention to their implementation and compliance with the treaty. Surprisingly, there is no significant relationship between a country's Torture Score (CIRI) and the quality of reports submitted. While a country's torture score weakly correlates with its responsiveness to Committee recommendations, this relationship is in the opposite direction than expected and loses significance when controlling for whether the country has recently democratized. Still, the finding that countries with abysmal records for torture are responding to the CmAT deserves follow up research.

Not surprisingly, countries that have made Article 22 Declarations are more likely to submit higher quality and responsive reports. Compared to governments that have not accepted the Committee's jurisdiction, Article 22 states on average submit higher quality reports $(+1.327$ Quality, indepen-

65. Compilation of Guidelines, supra note 18. 
Table 3. CAT Report Quality

\begin{tabular}{lcc}
\hline \hline & $(1)$ & $(2)$ \\
GDP per capita & 0.304 & 0.405 \\
(logged) & $(0.391)$ & $(0.407)$ \\
NHRI & -0.063 & 0.020 \\
& $(0.319)$ & $(0.318)$ \\
Torture Score & 0.030 & 0.093 \\
(CIRI) & $(0.229)$ & $(0.230)$ \\
Article 22 & 0.002 & -0.059 \\
Declaration & $(0.347)$ & $(0.355)$ \\
& & -0.088 \\
Human Rights Treaties (Proportion Ratified) & -0.094 & $(1.798)$ \\
& $(1.702)$ & 0.062 \\
Polity IV & $0.136 * * *$ & $(0.054)$ \\
& $(0.041)$ & $1.100^{* *}$ \\
Newly Transitioned & & $(0.515)$ \\
Democracy & & 0.950 \\
Population & & $(1.178)$ \\
(logged) & & 283 \\
\hline Observations & 0.955 & \\
\hline
\end{tabular}

Note: ${ }^{*} \mathrm{p}<0.1 ;{ }^{* *} \mathrm{p}<0.05 ;{ }^{* * *} \mathrm{p}<0.01$

Ordered probit regression. Robust standard errors in parentheses. Dependent variable is Report Quality (all reports). Year and country fixed effects included in all models. All variables lagged one year except Population and Newly Transitioned Democracy.

dent t-test, $p<.001)$ and more responsive ones (+0.826 Responsiveness, independent t-test, $p<.001)$. However, when controlling for other factors, the significant relationship between Article 22 Declarations and report Quality and Responsiveness disappears. Article 22 Declarations represent a stronger commitment to the CAT rules, but some governments might also be concerned that admissions made within their reports could be used against them by individual complainants in future proceedings.

At first glance, governments more deeply embedded in the international human rights system (Human Rights Treaties (Proportion Ratified)) appear to submit higher quality reports on average. This finding seems at odds with the argument that many states are insincere ratifiers, as we would not necessarily expect these states to be willing to provide more information about deficiencies in implementation of and compliance with the treaty. However, when controlling for other factors, the importance of human rights linkages for both report Quality and Responsiveness loses statistical significance. 
Table 4. CAT Report Responsiveness

\begin{tabular}{|c|c|c|}
\hline $\begin{array}{l}\text { GDP per capita } \\
\text { (logged) }\end{array}$ & $\begin{array}{c}(1) \\
0.163 \\
(0.773)\end{array}$ & $\begin{array}{c}(2) \\
0.144 \\
(0.783)\end{array}$ \\
\hline NHRI & $\begin{array}{c}1.869 * * * \\
(0.600)\end{array}$ & $\begin{array}{l}2.268^{* * *} \\
(0.671)\end{array}$ \\
\hline $\begin{array}{l}\text { Torture Score } \\
(\mathrm{CIRI})\end{array}$ & $\begin{array}{c}-0.885^{* *} \\
(0.405)\end{array}$ & $\begin{array}{l}-0.379 \\
(0.465)\end{array}$ \\
\hline $\begin{array}{l}\text { Article } 22 \\
\text { Declaration }\end{array}$ & $\begin{array}{c}0.190 \\
(0.347)\end{array}$ & $\begin{array}{c}0.213 \\
(0.966)\end{array}$ \\
\hline Human Rights Treaties (Proportion Ratified) & $\begin{array}{l}5.980^{*} \\
(3.393)\end{array}$ & $\begin{array}{l}3.115 \\
(3.535)\end{array}$ \\
\hline Polity IV & $\begin{array}{c}0.135 \\
(0.154)\end{array}$ & $\begin{array}{c}-0.417^{*} \\
(0.225)\end{array}$ \\
\hline $\begin{array}{l}\text { Newly Transitioned } \\
\text { Democracy }\end{array}$ & & $\begin{array}{c}5.059 * * * \\
(1.386)\end{array}$ \\
\hline $\begin{array}{l}\text { Population } \\
\text { (logged) }\end{array}$ & $\begin{array}{c}17.521^{* * *} \\
(6.129)\end{array}$ & $\begin{array}{c}17.286^{* * *} \\
(5.991)\end{array}$ \\
\hline Observations & 180 & 180 \\
\hline
\end{tabular}

Note: ${ }^{*} \mathrm{p}<0.1 ;{ }^{* *} \mathrm{p}<0.05 ;{ }^{* * *} \mathrm{p}<0.01$

Ordered probit regression. Robust standard errors in parentheses. Dependent variable is Report Responsiveness (subsequent reports). Year and country fixed effects included in all models. All variables lagged one year except Population and Newly Transitioned Democracy.

With respect to domestic political characteristics, more democratic states (Polity IV) submit more thorough reports on average. ${ }^{66}$ In line with the general trend within democracies for improved transparency about government decisions and activities, ${ }^{67}$ democracies more readily recognize shortcomings in implementation of or compliance with their CAT obligations and adhere to a principle of transparency within their reports. This finding is stronger for Newly Transitioned Democracies. Although new democracies are less likely

66. The measure for De facto political opposition is not included within analyses of report Quality and Responsiveness because the distribution of this variable for governments that have submitted reports is highly skewed to the right. James R. Hollyer, B. Peter Rosendorff, \& James Raymond Vreeland, Democracy and Transparency, 73 J. PoL. 1191, 1202 (2011).

67. John M. Ackerman \& Irma E. Sandoval-Ballesteros, The Global Explosion of Freedom of Information Laws, 58 Admin. L. Rev. 85 (2006); The Right to Know: Transparency for an Open World (Ann Florini ed., 2007); James R. Hollyer, B. Peter Rosendorff, \& James Raymond Vreeland, Democracy and Transparency, 73 J. Pol. 1191 (2011). 
to report, those that do are much more likely to be thorough, transparent, and responsive to CmAT concerns and recommendations. This is an important finding, consistent with others about treaty effects in the literature. Simmons, for example, finds that partially democratic and transitioning countries are more likely to reduce torture after ratifying the CAT. ${ }^{68}$ Both of these patterns are consistent with the claim that treaty ratification and reporting stimulate domestic mobilization that leads to both better reporting and more serious efforts to comply. The quality of reporting for newly transitioned democracies suggests serious engagement by this subset of states in the international human rights regime.

\section{CONCLUSION}

This article has explored one of the most important institutions for dialogue between sovereign states and the international community: the process of reporting to treaty bodies on implementation of, and compliance with, international human rights agreements. It focused on one of the most difficult cases for monitoring via self-reporting-the Convention against Torture. Why are some governments much more willing than others to report their practices thoroughly and frankly, and to constructively engage with the CmAT's recommendations and concerns?

Two key findings include the role of NHRIs and the influence of the reporting patterns of others. Simply being a "wealthy" state is not associated with punctual reporting. However, having the institutional capacity or additional source of domestic pressure from a National Human Rights Institution certainly is associated with on time reporting. In fact, the presence of an $\mathrm{NHRI}$ was a better predictor of reporting than (admittedly crude) measures of torture. Moreover, the willingness to report appears highly conditional, with reporting by other states in a region positively influencing the likelihood of reporting in a given state. Unfortunately, the opposite is true as well: when neighboring states fail to report, this is taken as a signal that procedural noncompliance is "okay." Reporting is subject to social entropy: opting out only encourages others to do the same, and degrades expectations of procedural compliance with the regime. These findings suggest the potential value of a regional strategy to improve reporting habits and competencies. Working with clusters of geographic neighbors to improve reporting habits may be much more successful than focusing on the most (or the least) responsive states.

This study breaks new ground by systematically coding and explaining not only the record but also the quality of state reporting within the CAT. Quality is important if we understand the reporting exercise to be a serious conversa-

68. Simmons, supra note 45. 
tion about norms and best practices. Quality reports were associated not only with capacity (again, NHRIs were important to higher quality reporting), but also with conditions that suggest the importance of domestic politics in the reporting process. Unsurprisingly, democratic countries are much more forthcoming about their progress on implementation of and compliance with the CAT and more willing to recognize areas for improvement than nondemocratic ones. More interesting, this research reveals that although new democracies are less likely to submit reports. However, when they do, these reports tend to be: more transparent about implementation shortcomings, more thorough in proposing measures to address deficiencies, and more responsive to Committee concerns. This finding is consistent with a growing body of research that views the explicit embrace of international human rights norms as an integral aspect of the domestic process of mobilization, dialogue, and commitment making. ${ }^{69}$ There are good reasons to believe that newly democratic regimes enhance their credibility (and satisfy mobilized domestic audiences) by engaging as thoroughly and frankly as possible with "official representatives" of the international human rights community.

Future research should concentrate on the value of the human rights reporting system for improving rights on the ground. There are several reasons to expect that a robust reporting regime may contribute to better human rights in states that take the process seriously. Self-reporting provides information for domestic audiences who have a stake in their government's implementation of international agreements, and may even set in motion bureaucratic routines to gather, authenticate and analyze information that might not have occurred in the absence of the obligation to report. To this extent, it is possible that reporting helps develop an autonomous capacity to self-monitor. As this article has emphasized, reporting is not simply a procedural obligation, but also an opportunity for government officials to learn about and become socialized into the human rights regime.

Furthermore, self-reporting represents an opportunity for citizens and domestic civil society to organize, to mobilize, to participate in, and to shape their government's human rights laws, institutions, and practices. Very little is currently known about how state reports or the Committee's concluding observations play out within domestic politics or whether domestic groups largely ignore these documents. Is the report discussed within the local press? Do nongovernmental organizations use the reports to legitimate their demands or to contradict the claims of the regime? Are the reports or concluding observations discussed in parliamentary debates or mentioned by opposition leaders? Future research should explore whether and how the degree and quality of governments' and citizens' participation in this dialogue affects rights practices on the ground.

69. Id. (on the role of domestic mobilization for human rights protections). 